IJLM

30,2

Received 6 July 2017

Revised 19 January 2018

31 July 2018

30 November 2018

Accepted 4 January 2019

\section{Strategic partner evaluation criteria for logistics service provider networks}

\author{
Hella Abidi \\ Department of Information, Logistics and Innovation, \\ Vrije Universiteit Amsterdam, Amsterdam, The Netherlands \\ Wout Dullaert \\ Faculty of Economics and Business Administration, \\ Vrije Universiteit Amsterdam, Amsterdam, The Netherlands \\ Sander De Leeuw \\ Department of Information, Logistics and Innovation, \\ Faculteit Economische wetenschappen en Bedrijfskunde, \\ Vrije Universiteit Amsterdam, Amsterdam, The Netherlands and \\ Nottingham Business School, Nottingham Trent University, Nottingham, UK \\ Darek Lysko \\ Department of Information, Logistics and Innovation, \\ Faculteit Economische wetenschappen en Bedrijfskunde, \\ Vrije Universiteit Amsterdam, Amsterdam, The Netherlands, and \\ Matthias Klumpp \\ FOM Hochschule, Essen, Germany
}

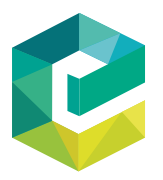

The International Journal of Logistics Management Vol. 30 No. 2, 2019 pp. $438-466$ Emerald Publishing Limited 0957-4093 DOI 10.1108/IJLM-07-2017-0178

\begin{abstract}
Purpose - The purpose of this paper is to establish criteria for evaluating strategic partners in a network of logistics service providers (LSPs) to show how analytical network process (ANP) can be used to identify the weights of these criteria on a case-specific basis, and to investigate whether the ANP model can be used as a starting point to evaluate strategic partners for other LSP networks.

Design/methodology/approach - Based on a literature review of vertical cooperation, the authors develop an overview of criteria for the evaluation of partners in a network of LSPs. The authors then apply ANP at LSP1 to validate the criteria, identify weights for these criteria and to validate model outcomes. Furthermore, the authors investigate whether the ANP model developed for LSP1 can be applied to another LSP with similar characteristics (LSP2). In-depth interviews are used to draw conclusions on the modeling approach and the model outcomes. Findings - The research shows that evaluation criteria for partners in vertical partnerships between shippers and LSPs are applicable to LSP partners in horizontal partnership networks. The ANP model with criteria weights provides a good starting point for LSPs to customize the evaluation framework according to their specific needs or operating environments.

Originality/value - Limited research is available on evaluating LSP partners in horizontal partnerships. To the best of the authors' knowledge, this paper is the first to bring forward horizontal LSP partner evaluation criteria to develop an ANP model for LSP partner evaluation and to apply this to two cases, and to provide a starting point for evaluating partners in similar horizontal LSP networks.
\end{abstract}

Keywords Europe, AHP, Logistics industry, Logistics services, Logistics clusters

Paper type Research paper

(C) Hella Abidi, Wout Dullaert, Sander De Leeuw, Darek Lysko and Matthias Klumpp. Published by Emerald Publishing Limited. This article is published under the Creative Commons Attribution (CC BY 4.0) licence. Anyone may reproduce, distribute, translate and create derivative works of this article (for both commercial and non-commercial purposes), subject to full attribution to the original publication and authors. The full terms of this licence may be seen at http://creativecommons.org/licences/by/4.0/legalcode 


\section{Introduction}

In recent years, many companies have been active in developing cooperative networks of firms. Cooperation within a business network supports companies in reaching their goals, in responding to market opportunities and in developing products with competitive prices and high product quality (cf. Zacharia et al., 2009). In the airline industry, cooperation between airlines in the form of a strategic alliance is increasingly being perceived as an essential element of business networks (Liou, 2012). Networks among airlines like Star Alliance, Sky Team and One World are made to attract more passengers, to expand networks, to provide cost reductions and to take advantage of product and service complementarities such as joint luggage handling, code sharing and gates and check-in counters (Liou et al., 2011). In the maritime industry, networks of ocean liner shipping companies are also well known (often referred to as the liner conference system (cf. Shashi Kumar, 1999)). These conferences can focus on specific aspects, e.g., route-specific ventures, vessels sharing and slot sharing agreements (Midoro and Pitto, 2000; Panayides and Wiedmer, 2011). Examples of these global networks in the maritime industry are the shipping line alliances, such as CKYH Alliance, the Grand Alliance and the New World Alliance (Panayides and Wiedmer, 2011).

Similar to other transportation sectors, logistics service providers (LSPs) active in road transport and logistics engage more and more in forming networks with partner LSPs. This type of cooperation is often referred to as horizontal cooperation and is aimed at reducing activity costs through load consolidation, joint-route planning and group purchasing (Pérez-Bernabeu et al., 2015, p. 586). LSPs also seek to exploit win-win situations (Pomponi et al., 2015) and combine resources and competencies in their logistics networks by cooperating horizontally (Raue and Wallenburg, 2013). Such cooperation with other LSPs enables LSPs to offer more comprehensive service packages, to reach more customers, to obtain more cargo, to use facilities more efficiently, and to develop and provide more effective logistics solutions (Carbone and Stone, 2005; Cruijssen, Cools, and Dullaert, 2007; Cruijssen et al., 2010) compared to what could be achieved individually (Pomponi et al., 2015). Such cooperation also occurs even though companies may compete with each other. In fact, Cruijssen, Cools, and Dullaert (2007, p. 135) show that the proposition that LSPs cooperate on core activities was supported the strongest in their survey (75.9 percent of the respondents agreed or strongly agreed with this proposition). Moreover, formal hypothesis testing allowed the authors to conclude (Cruijssen, Cools, and Dullaert, 2007, p. 138) that "Since smaller companies have smaller economies of scale and can thus operate less efficiently individually, they could benefit from forming a coalition in order to compete more effectively with larger companies." Therefore, it becomes more and more crucial to evaluate LSPs in horizontal partnership as a company's position in the market is affected by the performance and quality of its partners (Kannan and Tan, 2002).

So far, studies in the transportation industry on logistics partner evaluation have predominantly been oriented toward evaluating vertical logistics cooperation among strategic partners (i.e. the cooperation between an LSP and a shipper who owns the freight; cf. Dickson, 1966; Weber et al., 1991; Geringer, 1991; Wang and Kess, 2006; Jharkharia and Shankar, 2007; Büyüközkan et al., 2008; Ho et al., 2010; Chen and Wu, 2011). Martin et al. (2018) argued that horizontal cooperation between LSPs in the transportation industry and logistics industry is a fairly recent phenomenon; the research body on this topic is rather limited. They state that several other horizontal cooperation aspects LSP networks, especially at the strategic and management level (to which LSP partner evaluation in an LSP network belongs), are still scarcely researched. With regard to strategic partner evaluation, the literature contains only few studies from the transportation industry that focus on how to evaluate a horizontal partner. These scarce studies typically use evaluation criteria that are derived from vertical cooperation. Examples are Liou (2012) and Liou et al. (2011), who evaluated strategic alliances in the airline industry using criteria from vertical cooperation. 
IJLM

30,2

Solesvik and Westhead (2010) examined criteria for strategic alliances from maritime industries based on studies on vertical cooperation.

The main reason for a distinction between horizontal and vertical logistics cooperation is the existence of differences in goals. The goal of vertical cooperation is to establish mutual benefits between (vertical) actors in the supply chain. Typically, these partnerships are established to minimize logistics costs and waste, and to improve their performance in terms of delivery and quality of their products and services. Partners in horizontal cooperation aim to offer complementary services to avoid unnecessary logistics costs (Cruijssen, Cools, and Dullaert, 2007; Verdonck, 2017). Horizontal cooperation among LSP partners increases the productivity of core activities such as transportation and warehousing, reduce the costs of supporting logistics costs and allow companies to efficiently transport volumes that are too small to transport efficiently for the individual LSPs (Cruijssen, Dullaert and Fleuren, 2007). As acknowledged by Martin et al. (2018), cooperation among LSPs has become an important research area, since severe competition in global markets, rising costs and heightened customer expectations have caused profit margins of companies to decrease. As far as we know, to date there has been no study yet focusing on developing criteria for evaluating horizontal LSP partners, despite the fact that horizontal cooperation among LSPs is growing in importance (Cruijssen, Cools, and Dullaert, 2007; Raue and Wallenburg, 2013; Martin et al., 2018).

In this study, we first aim to develop an approach for evaluating LSP partners involved in horizontal cooperation. Similar to studies in the aviation and maritime industry, we start from evaluation criteria for vertical cooperation to develop a framework of evaluation criteria for horizontal cooperation among LSPs. To this end, we examine the literature on vertical logistics cooperation in logistics networks. These criteria are then used to develop a framework for horizontal LSP partner evaluation.

Second, we aim to show how these criteria can be used to develop a model for evaluating LSP partners in LSP networks. We apply analytical network processing (ANP) at a case company to determine the relative weights of the criteria derived from the literature. We chose ANP because it is a well-known model to deal with partner evaluation and selection problems (Talluri et al., 2006). We conducted the ANP model development at a medium-sized Dutch LSP (referred to as: LSP1) that had already constructed a network of LSPs for international transport and distribution activities. The results of an ANP study are typically context-specific. Therefore, most of the papers that develop ANP models present results that are applicable to the particular case considered (Meade and Presley, 2002). However, we contend that our ANP model for partner evaluation may provide a good starting point for the evaluation of strategic partners in similar transport and distribution networks. The third purpose of this paper is therefore to investigate to what extent our ANP model can be used as a starting point for cases that are similar in scope. To this end, we used the ANP results of LSP1 to evaluate five horizontal partnerships of another LSP (LSP2, a large internationally operating family-owned German LSP) and to discuss the extent to which the criteria as well as their relative importance as proposed by the ANP model based on LSP1 apply to other situations.

This paper is subdivided into six sections: Section 2 presents the research design and data collection procedure for the application of ANP. Section 3 reviews the background literature on criteria considered when evaluating partners within vertical cooperation to build a framework for evaluating LSPs in networks. In Section 4, an ANP-based decision-making model is presented based on a case with LSP1. Section 5 applies this model to five strategic horizontal partnerships of LSP2 and discusses the general applicability of this model based on interviews. In Section 6, we discuss differences and similarities in partner evaluation criteria between horizontal and vertical cooperation as well as the wider use of our ANP model. We conclude the paper in Section 7. 


\section{Research design}

Our research started with the development of a framework of evaluation criteria using literature from vertical cooperation between shippers and LSPs. Using an approach similar to Liou et al. (2011), we performed a structured literature review and obtained input from three LSP managers to make an overview of partner evaluation criteria.

In a second step, this framework is applied to a case study to show how these criteria can be used for evaluating LSP partners in horizontal cooperation. Since partner evaluation deals with many conflicting objectives, different criteria need to be considered for evaluating partner (Büyüközkan and Görener, 2015). Evaluation of strategic partners is a multi-criteria issue due to the nature of tangible and intangible criteria (Bhutta and Huq, 2002). Multiple criteria decision-making is widely used for evaluating and ranking problems containing multiple, usually when criteria are conflicting (Işıklar and Büyüközkan, 2007). There are a wide variety of methods and models that may apply to and that have been used in the context of evaluating a business partner: simple scoring models (Dean and Nishry, 1965), data envelopment analysis (Talluri and Baker, 2002; Sarkis and Talluri, 2006; Saen, 2007), analytical hierarchy process (AHP) (Bhutta and Huq, 2002; Chan et al., 2007; Büyüközkan et al., 2008), combinations of AHP with single-process methods (Sevkli et al., 2007; Forkmann et al., 2012; Ramanathan, 2013), analytical network process (ANP) (Bayazit, 2006; Sarkis and Talluri, 2006; Celebi et al., 2010). ANP is commonly used in strategic partner selection and evaluation procedures for vertical logistics cooperation (Ho et al., 2010; Bruno et al., 2012) and has been applied to related settings before. Sarkis and Talluri (2006) applied ANP to supplier selection and supported their findings with a numerical example. Bayazit (2006) used ANP as a tool for multi-objective vendor selection decisions. Çelebi et al. (2010) used an ANP model for determining if logistics services need to be kept in-house or be outsourced. Forkmann et al. (2012) applied ANP for establishing the relationship between networking strategy changes and the amount of factors influencing these changes. We therefore believe that ANP is an appropriate methodology given the research purpose since it enables the evaluation of relational dependencies for evaluation criteria, within categories and between categories of criteria. The use of ANP allows for incorporating dependencies between criteria as well as expert feedback, thus providing an accurate prediction for the priorities derived from the expert judgments (Saaty and Vargas, 2012).

In our study we applied ANP at a medium-sized Dutch LSP to define the relative importance of the partner evaluation criteria. The medium-sized Dutch LSP (referred to as LSP1) had already constructed a network of LSPs for international transport and distribution activities. LSP1 offers transportation, warehousing, customs clearance, value-added services and access to the track and trace system. LSP1 calls itself "one-stop shopping" where a client gets all support required from warehousing to transportation and where partners play an important role.

Third, we apply ANP to a second case study with the aim to investigate the generalization of results. Typical sample sizes used to make such predictions using ANP are fairly small and only apply to the case considered (cf. Ramanathan, 2013). For research on partner evaluation using ANP, we found that sample sizes typically do not exceed 20 respondents (Jharkharia and Shankar, 2007: 6 respondents; Tseng et al, 2009: 11 respondents; Gencer and Gürpinar, 2007: 16 respondents). Respondents provide expert judgments for specific case circumstances, which may explain why such relatively small sample sizes apply (compared to large-scale surveys that focus on testing hypotheses). As a result, ANP models provide context-specific outcomes (since experts judge their own particular situation). This would imply the need to replicate ANP in every situation that one encounters even if problems are similar in nature. In this paper, we therefore investigate whether the results from an ANP model from one organization may be used in another, yet somewhat similar organization. To this end, we applied the results of the study at LSP1 to 
IJLM

30,2

an LSP in a comparable situation (LSP2). LSP2 is larger in size (over €5bn annual turnover with 20,000 employees worldwide, but also family-owned like LSP1). In a similar way as Ramanathan (2013), who discusses the results of AHP (an earlier variant of ANP) with management in interviews, we employed interviews to investigate whether the ANP model developed for LSP1 also applies to five partnerships of LSP2. We furthermore conducted interviews to discuss findings and in particular whether the horizontal LSP partner evaluation criteria developed with LSP1 apply more generically or require amendments or additions before application elsewhere. Section 5.2 provides further detail on the approach taken in these interviews.

\section{Background literature on criteria for partner evaluation}

Based on a literature survey, Martin et al. (2018) argue that research in the domain of decision frameworks for horizontal collaboration is limited and therefore state "[...] publications regarding the decision process in horizontal collaboration are rather scarce" (p. 34). Similar to other studies on horizontal partner evaluation in the transportation industry (Liou et al., 2011; Liou, 2012), we therefore base our framework of evaluation criteria for horizontal LSP partnerships on criteria for vertical logistics partnerships. To determine the factors that determine successful vertical logistics partnerships, we conducted a structured literature review based on the approach described in Denyer and Tranfield (2009). Using this approach, we identified 18 criteria, which we grouped into four categories similar to the work of Liou (2012) on horizontal partnerships in the airline industry: financial criteria, organizational criteria, operational performance criteria and strategic criteria. In the following subsection, we discuss each of these categories and provide an overview of the criteria in Table I.

\subsection{Financial criteria}

The financial resources of partners can be as important as their operating capabilities (Miller, 1998). Financial stability (No. 1) is critical because if an organization is financially stable there is less risk of bankruptcy and related consequences (Büyüközkan et al., 2008; Chen and $\mathrm{Wu}, 2011$ ). Sharing revenue (No. 2) in a fair manner is another key feature for successful close cooperation with partners (Lambert, 2008; Rezaei et al., 2016). Revenue sharing is used to distribute revenues/profits achieved from a business partnership (Andersson and Norrman, 2002; Rese, 2006). Finally, having the right sales strategy (No. 3) to minimize transaction and production costs is a prerequisite for the financial success of a partnership (Liou, 2012; Luo et al., 2009). Minimizing transaction and productions costs (No. 4) is crucial within a partnership because this allows for maximizing transaction value (Dyer, 1997; Jharkharia and Shankar, 2007).

\subsection{Organizational criteria}

Successful cooperation between partners goes beyond financial abilities and includes organizational abilities and trustworthiness. Trustworthiness (No. 5) between partners creates a better work environment, reduces uncertainties, increases productivity and enhances flexibility. A situation in which a firm trusts its partners leads to relationship commitment and more sustainable partnerships (Chen and Wu, 2010; Lai et al., 2010; Zaefarian et al., 2013).

To maintain a sustainable partnership, know-how (No. 6) and knowledge transfer are crucial (Lambert, 2008; Büyüközkan et al., 2008). The presence of high-quality knowledge and skilled employees increases sales performance, strengthens relationships between partners, and improves operational and relational outcomes. Together these lead to competitive advantage, efficient asset usage, high customer satisfaction and profitability (Lai, 2009). Ultimately, skilled employees lead to effective communication (No. 7) within a partnership, which is important because effective communication facilitates the 


\begin{tabular}{|c|c|c|}
\hline Criteria & Description & Authors/year \\
\hline \multicolumn{3}{|l|}{ Financial (FIN) } \\
\hline $\begin{array}{l}\text { 1. Financial } \\
\text { stability (FST) }\end{array}$ & $\begin{array}{l}\text { If an organization is financially stable there is less risk of a } \\
\text { bankruptcy }\end{array}$ & $\begin{array}{l}\text { Büyüközkan et al. (2008), } \\
\text { Chen and Wu (2011) }\end{array}$ \\
\hline $\begin{array}{l}\text { 2. Revenue } \\
\text { sharing (REV) }\end{array}$ & $\begin{array}{l}\text { It is important to negotiate how revenue generated during } \\
\text { the partnership will be split between parties }\end{array}$ & $\begin{array}{l}\text { Andersson and Norrman } \\
\text { (2002), Rese (2006), } \\
\text { Lambert (2008), Rezaei } \\
\text { et al. (2016) }\end{array}$ \\
\hline 3. Sales (SAL) & $\begin{array}{l}\text { This encompasses a company's level of sales activity and } \\
\text { number of customers. A good sales team is a prerequisite for } \\
\text { success }\end{array}$ & $\begin{array}{l}\text { Liou (2012), Luo et al. } \\
(2009)\end{array}$ \\
\hline 4. Cost (CST) & $\begin{array}{l}\text { This includes transaction and production costs. Transaction } \\
\text { costs consist of four elements: search, contracting, } \\
\text { monitoring and enforcement. Production costs describe total } \\
\text { logistics costs and are usually composed of cost per km, cost } \\
\text { per shipment and inventory carrying costs }\end{array}$ & $\begin{array}{l}\text { Dyer (1997), Huang and } \\
\text { Keskar (2007), Jharkharia } \\
\text { and Shankar (2007), Liou } \\
\text { (2012), Luo et al. (2009) }\end{array}$ \\
\hline
\end{tabular}

Strategic partner evaluation criteria

443

Organizational (ORG)

5. Trust (TR) Mutual trust can come from financial stability and achievements. As potential alliance partners can be

Bernal et al. (2002),

Büyüközkan et al. (2008),

Teo et al. (2009), Chen and $\mathrm{Wu}$ (2010), Lai et al. (2010), Zaefarian et al. (2013)

6. Know-How $(\mathrm{KH})$ Because one organization is performing on behalf of another Lambert (2008), having the technical expertise to perform the service is required

7. Communication Cooperating with firms that have similar hierarchical Yang (2009), Cao et al. (CMN) communication structures facilitates mutual understanding with regard to communication and decision-making

8. Family business Establishing a partnership with another family-owned (FB) business increases the chance for long-term engagement and also the likelihood that there is a match between the cultures

9. Cultural fit (CF) Having comparable cultures increases understanding of the underlying meanings of processes and procedures in an organization

(2010), Chen and $\mathrm{Wu}(2010)$

Svensson (2004),

Audy et al. (2012)

Büyüközkan et al. (2008),

Chen and $\mathrm{Wu}(2010)$

Operational performance (PFRM)

10. Quality (QLT) This is measured by two aspects: orders received with no damage and orders received accompanied by proper documents

Ho et al. (2010), Jharkharia

11. On-time Delivery is measured by two parameters: on-time delivery

Delivery and completed orders received

kar (2007)

Zeydan et al. (2011)

(DLV)

12. Service (SER) The organizations' flexibility toward the clients' wishes and needs, e.g., their service range and ability to respond

Kannan and Tan (2002), Liou (2012), Sharma et al. (2008), Simpson et al. (2002) Golmohammadi and Mellat-Parast (2012)

Strategic (STR)

13. Growth (GRW) The business partners need to agree on a growth strategy

14. IT capabilities Good IT capabilities lead to a reduction in both inventory (IT) levels and uncertainties in the process

Jharkharia and Shankar (2007), Büyüközkan et al. (2008)

Jharkharia and Shankar (2007), Büyüközkan et al. (2008), Wu and Barnes (2010), Chen and $\mathrm{Wu}$ (2011), Cao et al. (2010)
Table I. Literature review on criteria 
15. Information exchange

(INF)

\section{4}

Table I.

16. Long-term engagement (LTE)

17. Network (NTW)

18. Inventory
Information exchange incorporates mutual trust issues. It is
necessary to exchange information not only for smooth
daily operations but also for continuous improvement

Chen and $\mathrm{Wu}(2010)$

Forkmann et al. (2012),

Lee and Cavusgil (2006),

$\mathrm{Wu}$ and Barnes (2010),

Zaefarian et al. (2013) turnover (INV)
The level of trust determines the long-term prospects of the Kannan and Tan (2002), alliance. Financial stability, past achievements, and having Jharkharia and Shankar a good relationship increases the level of trust among (2007), Büyüközkan alliance partners as well as the level of commitment toward et al. (2008) the alliance

A supply chain is a network of organizations involved in a Jharkharia and Shankar variety of processes and activities that produce value in the (2007), Büyüközkan form of products and services for the ultimate consumer. The potential business partner should be willing to be part of an interconnected network of LSPs

The ratio between incoming and outgoing goods of a particular period between partners. Ideally, the flow of goods is balanced both ways
Ha et al. (2011), Wu and Barnes (2010)

improvement of supply chain alliance performance (Yang, 2009) and supports information exchange that simplifies the coordination of business activities (Lee and Cavusgil, 2006; Wu and Barnes, 2010; Zaefarian et al., 2013).

In selecting a partner, it is important to have a good fit with partners in terms of culture and philosophy (Audy et al., 2012). In particular, family-owned (No. 8) companies may benefit from partnering with other family-owned companies. Cooperation between familyowned businesses increases the chance that there will be a cultural fit (No. 9) between partners and that the partnership will be sustained over the long term because partners often have similar philosophies, visions and organizational objectives (Svensson, 2004).

\subsection{Operational performance criteria}

Operational performance is one of the most critical evaluation factors cited in the literature on vertical partnerships (Huang and Keskar, 2007). A key aspect of operational performance is quality (No. 10), which encompasses accuracy of order fulfillment, cost of loss and damage, and commitment to continuous improvement (Jharkharia and Shankar, 2007; Ho et al., 2010; Zeydan et al., 2011). On-time delivery (No. 11) is furthermore an important aspect of operational performance within a supply chain because buffer inventories can be reduced if uncertainty is reduced (Kannan and Tan, 2002; Liou, 2012). Additionally, service levels (No. 12) such as on-time delivery demonstrate an organization's ability to respond flexibly to a client's requests (Golmohammadi and Mellat-Parast, 2012). High service levels may boost growth as business between partners expands and new markets are developed (Jharkharia and Shankar, 2007; Büyüközkan et al., 2008).

\subsection{Strategic criteria}

Growth (No. 13) relates to the opportunity for partners in cooperation to create new businesses and to minimize liabilities such as lack of IT capacities and capabilities. Having appropriate IT capability (No. 14) allows for information sharing and exchange, transparency, and knowledge development within a partnership (Büyüközkan et al., 2008; Wu and Barnes, 2010). Moreover, IT capability enables a partnership to create sustainable competitive advantage and to establish effective communication (Cao et al., 2010). Information exchange (No. 15) enriches the knowledge resources of a firm (Chen and Wu, 2010; Forkmann et al., 2012), increases confidence and builds 
mutual trust within a partnership (Teo et al., 2009). Long-term engagement (No. 16) in a partnership leads to the development of interdependent activities and resources, which are beneficial for productivity within the network (Kannan and Tan, 2002; Jharkharia and Shankar, 2007). Being part of a network (No. 17) is particularly advantageous if an alliance partner is already familiar with a market, has access to other parties and has acquired necessary information and resources (Jharkharia and Shankar, 2007; Büyüközkan et al., 2008). A widespread network also enables high inventory turnover (No. 18), which is particularly relevant for LSP customers since inventory is one of the largest assets on their balance sheets.

Strategic

partner

evaluation

criteria

445

\section{Using ANP for developing a horizontal LSP partner evaluation model at LSP1}

\subsection{ANP structure}

We use a case study at LSP1 to show how ANP can be used for the development of a horizontal LSP partner evaluation model. Figure 1 shows the ANP problem formulation

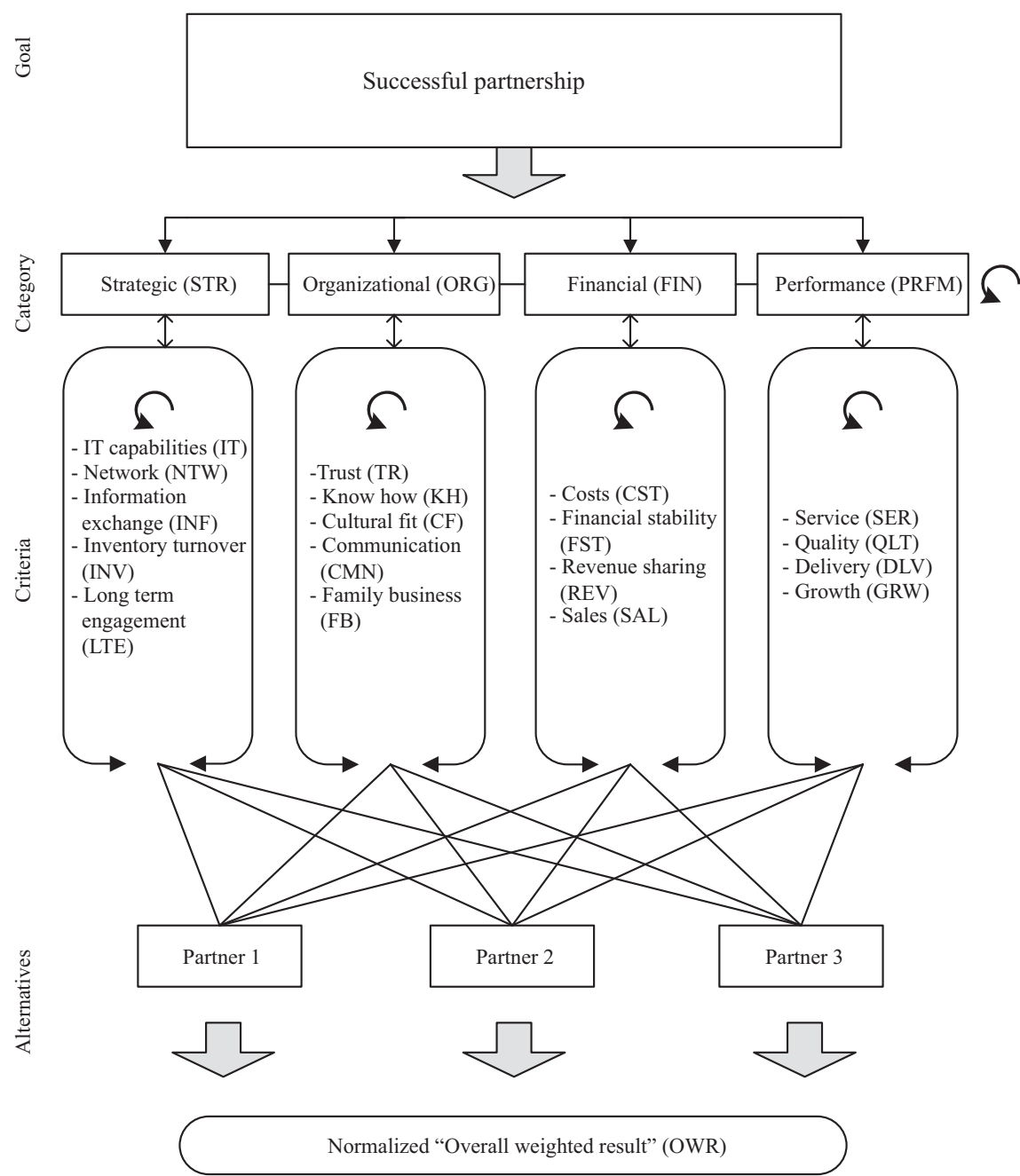

Figure 1 .

Partner evaluation structure 
IJLM

30,2

\section{6}

Table II.

Pairwise comparison of criteria categories

structure based on the evaluation criteria identified in the literature. The ANP structure contains the goal (a successful partnership), the four criteria categories (or clusters) and the criteria themselves. In ANP, each of the criteria receives a weight and partners are scored on each criterion, resulting in an overall weighted result (OWR) for each partner evaluated. These OWR scores can then be compared among the partners. Below, we will discuss the steps to establish the ANP model.

\subsection{Establishing priorities}

In order to identify priorities for the individual criteria, we composed an ANP questionnaire that includes comparison matrices. A scale of 1-9 was used to compare sets of two criteria, with 1 indicating that criteria are equally important and 9 indicating the extreme importance of one criterion over another. We piloted the ANP questionnaire with two persons (one from academia and one from practice) and adjusted it using their feedback. Sarkis (1998) suggested involving a variety of employees who have a stake in the final decision. Therefore, we selected potential respondents together with the board in order to guarantee sufficient spread among staff members who work directly or indirectly with customers and LSP partners. We sent the ANP questionnaire to 35 employees of LSP1 and received 26 responses (74 percent response rate). These numbers are well within the recommended sample sizes for such studies (cf. Zahedi, 1986; Jharkharia and Shankar, 2007; Gencer and Gürpinar, 2007; Tseng et al., 2009; Ramanathan, 2013). The resulting overall priorities of the ANP model are represented in an unweighted supermatrix (Table V) and a weighted supermatrix (Table VI).

Next, the interdependence of categories is established. A matrix presenting the interdependence of criteria categories, the eigenvectors and the consistency index is shown in Table II. The eigenvectors (e-vector) show the importance of each of the criteria and are composed using SuperDecisions software. The consistency of the data gathered is measured for each matrix using a consistency index (CI). The data are consistent if the $\mathrm{CI}$ is smaller than the threshold of 0.10 .

The relative importance of each criterion within a specific category is then established. As an example, the matrix representing the Strategic (STR) category is shown in Table III. This table shows the influence of criterion $a$ on the strategic category as compared to criterion $b$. Four matrices are developed in this step, one for every category (see Table AI).

\begin{tabular}{lccccc}
\hline Categories & STR & ORG & FIN & PRFM & Normalized e-vector \\
\hline Strategic (STR) & 1 & 3 & $1 / 3$ & $1 / 2$ & 0.163 \\
Organizational (ORG) & $1 / 3$ & 1 & $1 / 5$ & $1 / 6$ & 0.064 \\
Financial (FIN) & 3 & 5 & 1 & 2 & 0.465 \\
Performance (PFM) & 2 & 6 & $1 / 2$ & 1 & 0.308 \\
& & & & \multicolumn{2}{c}{ Consistency index: 0.027} \\
\hline
\end{tabular}

Table III.

Pair wise comparison of strategic criteria (STR)

\begin{tabular}{lcccccc}
\hline Strategic criteria & INF & INV & LTE & IT & NTW & Normalized e-vector \\
\hline Information exchange (INF) & 1 & 2 & 3 & 4 & 6 & 0.422 \\
Inventory turnover (INV) & $1 / 2$ & 1 & 2 & 3 & 4 & 0.257 \\
Long-term engagement (LTE) & $1 / 3$ & $1 / 2$ & 1 & 2 & 4 & 0.166 \\
IT capability (IT) & $1 / 4$ & $1 / 3$ & $1 / 2$ & 1 & 3 & 0.104 \\
Network (NTW) & $1 / 6$ & $1 / 4$ & $1 / 4$ & $1 / 3$ & 1 & 0.051 \\
& & & & & Consistency index: 0.026 \\
\hline
\end{tabular}


From Table III we, for example, observe that the importance of information exchange (INF) compared to long-term engagement (LTE) is valued at 3 (out of 9), which means that the preference of respondents is closer to INF than to LTE. INF is thus considered more important than LTE. Moreover, information exchange (INF) has the largest normalized eigenvector (0.422) in the strategic category, implying it is the most important within this category. The network (NTW) has the least importance (0.051) in the strategic category.

Table IV presents the relative importance of criteria considering information exchange (INF) between partners. It shows, for example, that IT capability (IT) is four times more important than long-term engagement (LTE) when considering information exchange between partners (INF).

We created 18 interdependency matrices, one for each criterion (see Table AII). The values from these 18 interdependency matrices are used to form an unweighted supermatrix (Table V). The unweighted supermatrix shows the relative importance of all the evaluation criteria. In order to obtain stable weights, the unweighted supermatrix is converted to a weighted matrix (Table VI). For convergence to take place, the sum of each column in the general matrix has to be equal to 1 .

\section{Applying and evaluating the ANP model - horizontal LSP partner evaluation at LSP2}

\subsection{Applying the ANP model}

Typically, ANP models are used to develop case-specific weights of evaluation criteria. Although criteria used may be similar different companies may place different weights on certain aspects, as, for example, in the case of a buyer-supplier situation as investigated by Ramanathan (2013). We believe there is merit in identifying a base ANP model that can be used as a point of reference for similar studies in evaluating horizontal LSP partners. To identify whether this is possible, we evaluated five horizontal partners of a second case company (LSP2) from five European locations, using the model developed for LSP1. The five partners are family businesses that run warehouses and offer a range of transport and logistics services like LSP2. These partners provide a large network with branches in countries in East-Europe, North Europe and West Europe. First, we asked the management of LSP2 to rank their five partners on the management's perception of their performance from 1 (best) to 5 (poor) (see Appendix 3). Second, we asked the management of LSP2 to apply our ANP framework and to judge the performance of each partner using a scale from 1 (extremely poor) to 9 (extremely good). Third, we discussed the rankings and ANP results with the management of LSP2 in an interview and evaluated whether certain aspects of performance were missing or needed to be incorporated in the evaluation model. This will be further discussed after the ANP results below.

In order to evaluate each of the five partners, an OWR is calculated, which represents the relative importance of each partner. A higher value indicates a better fit of the partner based on the weights of the evaluation criteria developed for LSP1. We calculated the OWR for the five partners as follows:

$$
O W R_{k}=\sum_{i=1}^{4} \sum_{j=1}^{18} C_{i} \times D_{j i} \times I_{j i} \times E_{k} .
$$

\begin{tabular}{lccccc}
\hline INF as dependent & INV & LTE & IT & NTW & Normalized e-vector \\
\hline Inventory turnover (INV) & 1 & $1 / 4$ & $1 / 4$ & $1 / 2$ & 0.047 \\
Long-term engagement (LTE) & 4 & 1 & 4 & 5 & 0.402 \\
IT capability (IT) & 4 & $1 / 4$ & 1 & 4 & 0.232 \\
Network (NTW) & 2 & 5 & $1 / 4$ & 1 & 0.320 \\
& & & & Consistency index: 0.270
\end{tabular}

\section{Strategic \\ partner \\ evaluation \\ criteria}


IJLM
30,2

\section{8}

Table V.

Unweighted

supermatrix (before convergence)

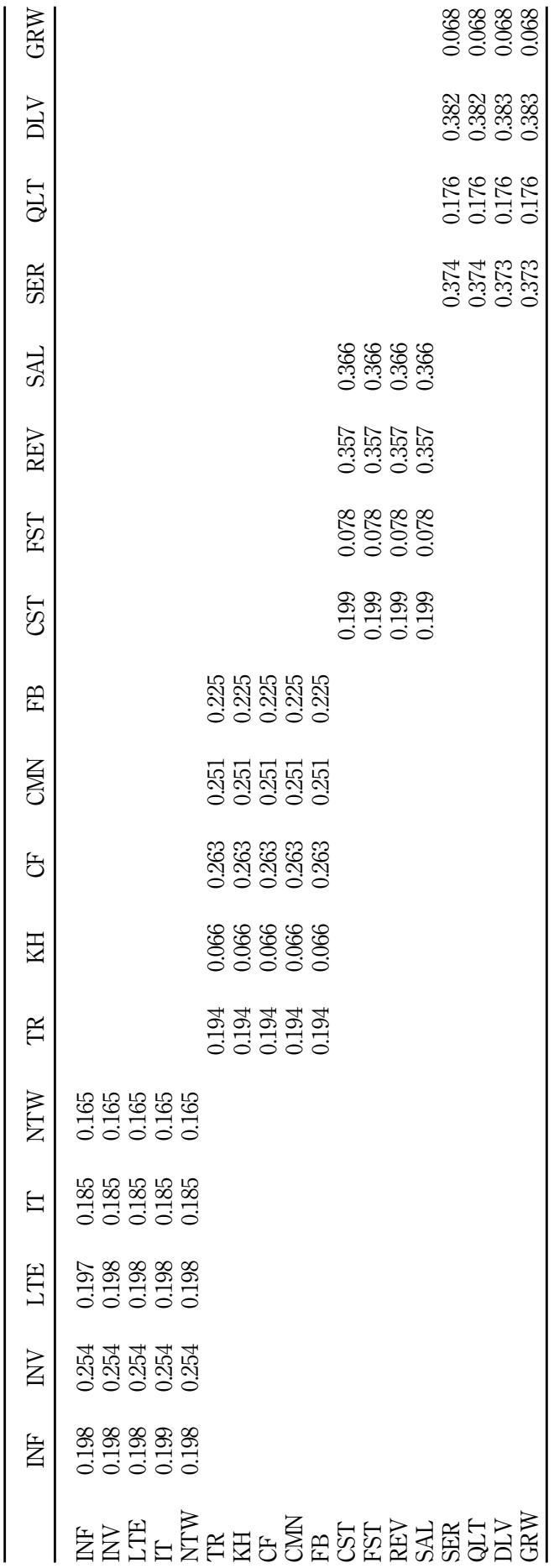




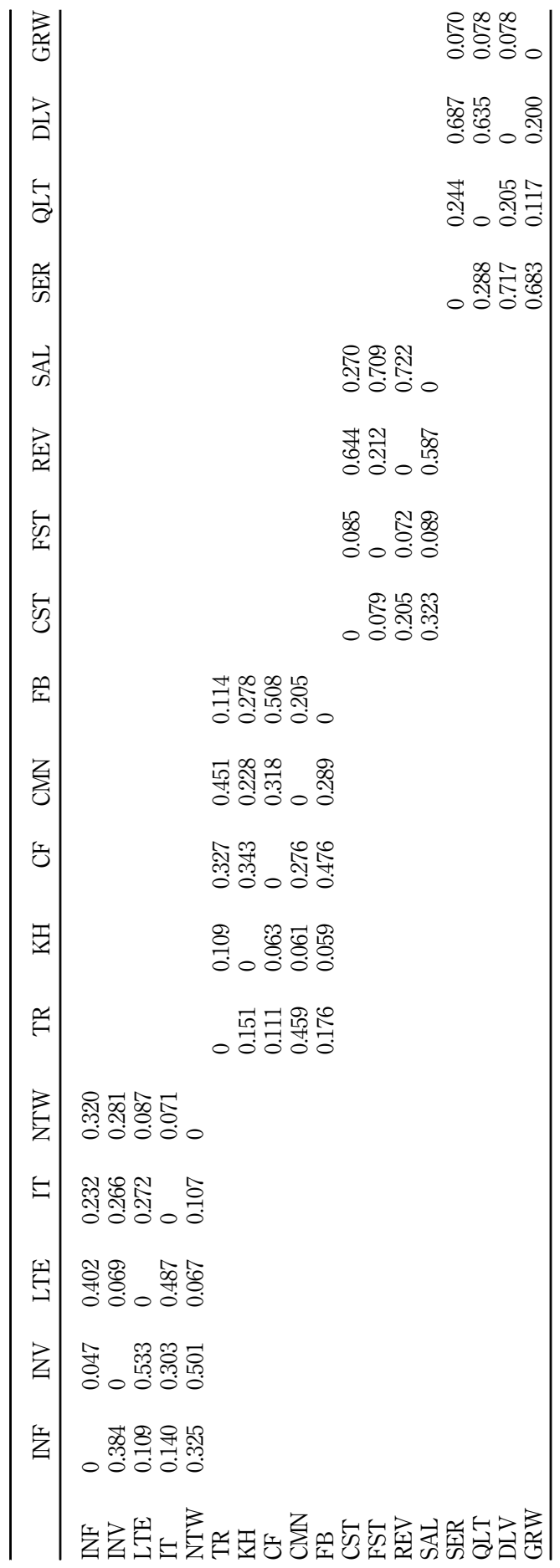

Strategic partner evaluation criteria

449 ํํํํํำ 홍경。总 옹 종영

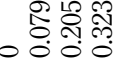
복웡융영

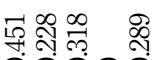

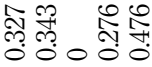

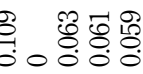

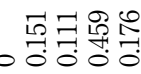


IJLM

30,2
In Equation (1), $i$ represents the number categories while $j$ is the number of criteria. $C_{i}$ is the relative impact of criteria category on the decision. $D_{j i}$ is the relative impact of criterion $j$ on its category $i$ for a dependency strength. $I_{j i}$ shows the stabilized relative impact of criterion $j$ on its category $i$. $E_{k}$ represents the weights given to five partners. The OWR figures are taken from the weighted supermatrix (Table VI). The OWR presented in Table VII represents the relative importance of the five partners. The third column in this table (labeled $C_{i}$ ) represents the importance of criteria categories; values are taken from Table V. Figures in the fourth column $\left(D_{j i}\right)$ represent the importance of individual criteria on their respective category based on Table VI. The fifth column represents stabilized values of interdependence between criteria $\left(I_{j i}\right)$ and values are imported from Table VII. The sixth, seventh and eighth columns represent the weights given to five partners based on the judgment by the management of LSP2.

We normalized the $O W R$ such that $\sum_{k=1}^{5} O W R_{k}=1$. The row "normalized $O W R$ " in Table VII contains the OWRs for each of the five partners. As can be seen from Table VII, Partner 4 has the highest normalized $O W R$ score (0.3812) and was therefore evaluated highest.

As outlined above, we asked the management to rank the five partners from the best performing partner (1) to the least performing (5). We compared this to the outcomes of the ANP exercise. It turned out that the results of the ranking by the management of LSP2 were the same as the results based on our ANP framework, except for the ranking of Partner 3 and Partner 5 (these were reversed in ranking).

\subsection{Evaluating the ANP model}

We then discussed the evaluation criteria and the applicability of the ANP model in 12 semi-structured interviews with managers from LSP2. The interviewees were selected based on their job title, main responsibilities in relation to partner evaluation at LSP2. The interviews aimed to discuss if there are missing criteria in the horizontal partner evaluation model established and verify if the relative importance of the criteria in our ANP model may apply to a variety of LSP partners in horizontal cooperation. The interviewees possessed on average more than 24 years of experience in the logistics and transport industry, are active across Europe and had worked for a variety of LSP companies before joining LSP2. Table VIII illustrates the list of the interviewees of the study, their job title and responsibilities.

An interview protocol was established (Appendix 4) as a guide for the interviews. All interviews were conducted via telephone. The interviews had a duration between 35 and $60 \mathrm{~min}$ and were recorded, transcribed and sent back to the interviewees for feedback and approval. As suggested by Eisenhardt and Graebner (2007), additional documentation, such as web pages (e.g. about horizontal partner organizations) were reviewed as secondary sources of empirical data.

The interviews did not reveal criteria that required deletion from the list. Two interviewees observed that green logistics criteria are missing in the applied ANP model. The interviewees indicated that since reliable electric trucks with a long range are not yet available, green logistics is not yet an evaluation criterion for partners. All in all, green logistics should be considered a partner evaluation criterion in horizontal LSP networks, though not yet now but in the future.

The interviews revealed that the ranking of the categories is applicable to a variety of LSP networks; however, the weights of the individual criteria will require adjustment on a case-by-case basis. In line with the LSP1-based ANP model outcomes, the interviewees at LSP2 agreed that the financial category should be leading in LSP partner evaluation. Several interviewees clarified that cooperating with a partner that is financially stable (FST) leads to a long-term relationship marked by mutual trust among the partners within an LSP network. Furthermore, a focus on costs (CST) by the partners was argued to be critical because cost is still a major consideration for customers. Of second importance is the 


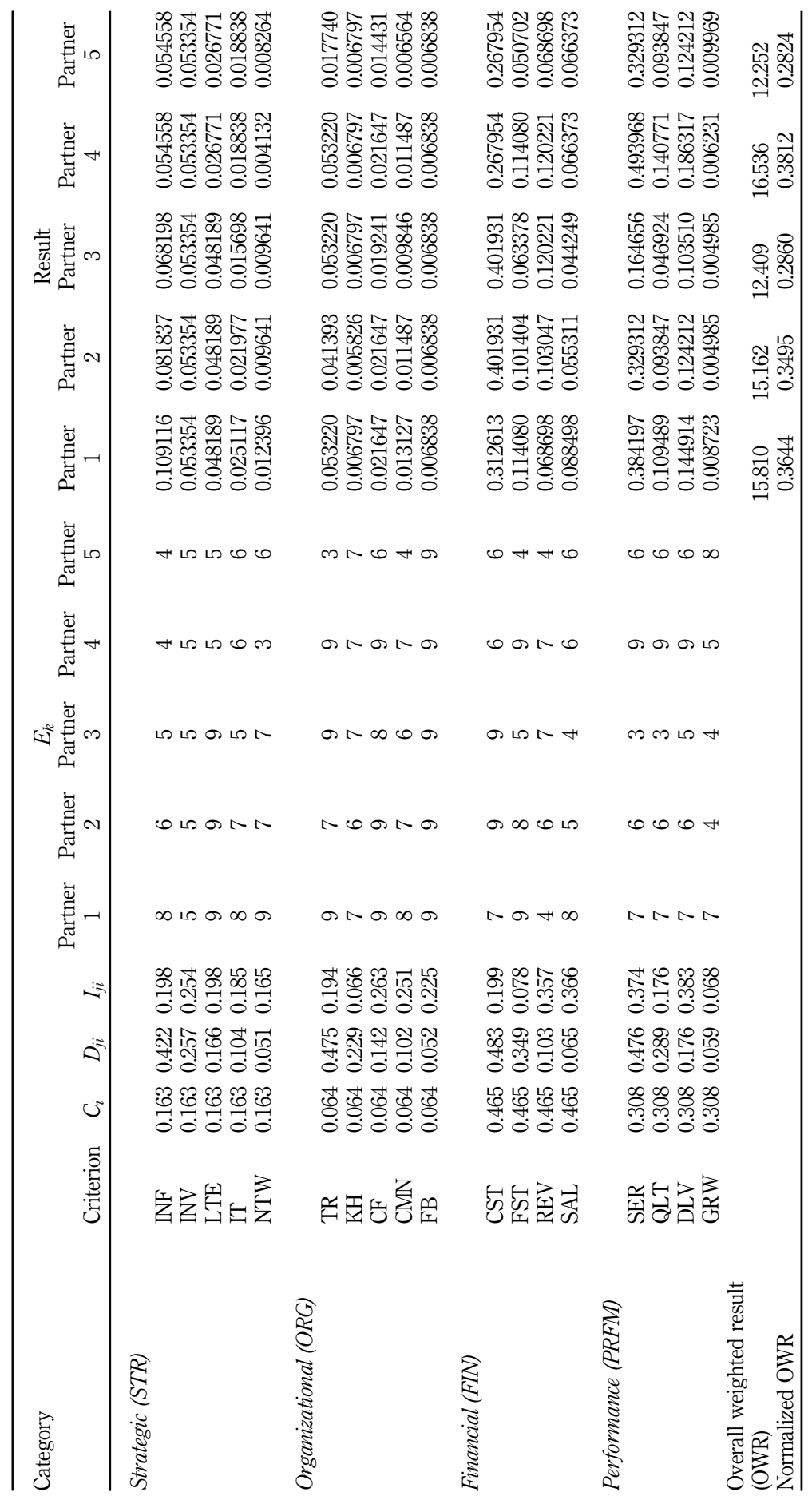

Strategic

partner evaluation

criteria

451

Table VII.

Presentation of overall weighted results (OWR) and their normalized values 
IJLM
30,2

General Managers $(7 \times)$

Head of Global LSP

Network $(1 \times)$

Managing Director $(1 \times)$

Production Manager

International Forwarding $(1 \times)$

Table VIII.

Job title, roles and responsibilities of interviewees at LSP2

Job title Network $(1 \times)$
Main responsibilities and relation to partner evaluation

Development of transportation and logistics solutions for the whole LSP network. Cooperate with different partners in order to implement the solutions in different locations worldwide. Provide input on a strategic level about the capabilities, capacities and cooperation willingness of partners Managing European transport, warehouse and logistics services within a specific city. Cooperate with partners at the tactical and operational level European wide. Provide inputs on the operational performance of partners to the headquarter

Responsible for network development and relationship management with partners worldwide. Evaluate and analyze the cooperation among the LSP network at strategic and operational levels. Identify bottlenecks and provides potential concepts in order to improve the partnership Managing transport, warehouse and logistics services in a country. Cooperate with partners at the strategic level worldwide. Provide inputs on the strategic and operational performance of partners to the headquarter Securing and developing international overland freight forwarding services. Discuss and provides concepts to partners in order to increase the volume of freight within an LSP network. Provide inputs on the operational performance of partners to the headquarter

Project Manager within an LSP Helping to identify and evaluate possible partners, and then project manage the integration of the partner into the network

category: operational performance. The managers interviewed explained that the ability of a partner to increase customer satisfaction (SER) and quality (QLT) is a key for keeping customers and extending cooperation with these customers. Increasing customer satisfaction is dependent on the service and quality offered by each LSP partner, which have to be continuously optimized. One manager explained that if a customer is not satisfied with the service level offered by an LSP, the customers might decide to work with another network of LSPs instead. The interviewees argued that this affects the growth and financial situation of the LSP, which turn leads to an increase in logistics costs and decreasing service levels. As a result, this category is important for both the financial and the strategic categories. The interviewees furthermore explained that the third-ranked category in terms of importance is the strategic category. From this category, they mentioned in particular sharing IT capabilities (IT) and information exchange (INF) to improve the synchronization of the information and material flow with the transport channel worldwide. The interviewees said that cooperation with LSP partners implies sharing infrastructure and resources and developing common standards. For example, IT is standardized in an LSP network to share information easily and process documents in an automated manner. This results in increased transport efficiency and reduced coordination effort within an LSP network, as well as enhanced mutual trust. The last category is the organizational category. The interviewees indicated that in this category particularly trustworthiness (TR) and cultural fit $(\mathrm{CF})$ are key because they stabilize the cooperation between partners and can mitigate conflict between contract partners. One interviewee indicated that because of the trust between partners imbalance in workload between two partners was not invoiced every time it occurred because the partners knew that relatively more work for one partner now would be offset by relatively more work for the other partner in the near future.

During the interviews, the usefulness of ANP for LSP partner evaluation was also discussed. Three of the interviewees indicated that they preferred the ANP model over scoring and matrix methods or more complex mathematical approaches. The proposed ANP model takes the middle road of these approaches, not requiring the complexity of the mathematical models, yet providing a robust solution. One of the interviewees criticized the 
fact that the criteria in the scoring approach are related to each other and appreciated that the ANP model explicitly takes interdependencies between the criteria into account through a pairwise comparison. Through the pairwise comparison within an ANP network structure, the decision makers can understand trade-offs between the criteria. According to the managers interviewed, the major advantage of the ANP model is that it compelled them to think in a comprehensive and detailed manner about the partnerships and provides an objective approach to evaluate partners. The interviewees also expressed their expectation that the weights of the individual criteria in the ANP model required some adaptation dependent on, e.g., industry focus of the LSP (e.g. transporting chemicals has different requirements than transporting large capital goods) or the geographic focus (national vs international focus of an LSP, which relates to the ability to deal with different cultural aspects). However, they also indicated that overall the relative importance of the categories will be similar across LSPs.

\section{Discussion}

\subsection{Vertical vs horizontal partnership evaluation}

In our research, we studied criteria to evaluate horizontal partnerships in logistics networks using criteria from vertical partnership studies, similar to other studies (Jharkharia and Shankar, 2007; Büyüközkan et al., 2008; Wu and Barnes, 2011). We noted that criteria from vertical cooperation research are indeed useful to evaluate horizontal cooperation based on the conducted interviews. Our interviews did not reveal any additional horizontal partnership evaluation criteria that we needed to add to the criteria derived from vertical partnership studies. The driving force behind horizontal and vertical cooperation are high fixed costs involved in doing business, striving to increase the quality of the performance and dealing with the complexity of serving a global market (Bernal et al., 2002; Verstrepen et al., 2009). Both cooperation types support doing business for each partner involved in a logistics network in order to respond to market requirements.

Since the partner evaluation criteria appear overall the same for these two types of cooperation, our research does show slight differences in the relative importance of the individual criteria. The interviews showed that the most important financial criteria considered in evaluating horizontal cooperation among LSPs are financial stability and price/cost. In vertical cooperation, revenue-sharing benefits and price/profit margin are typically the most relevant financial criteria (Yang, 2009).

In the category operational performance, quality and customer satisfaction were considered most relevant for horizontal cooperation in the interviews. These criteria are also highly ranked criteria for evaluating partners in vertical cooperation. Customer satisfaction relates to many factors like accuracy of order fulfillment or promptness in attending customers' complaints; quality is characterized by providing good service and a managing operational performance well (Jharkharia and Shankar, 2007). These criteria are useful for both vertical and horizontal cooperation because they enhance competitive positions or market power, improve operational processes and allow focus on a narrow range of activities and engage in complex interactions with other firms (cf. Cruijssen, Dullaert and Fleuren, 2007).

For horizontal cooperation, the key strategic criteria were identified as information capabilities and IT capabilities, which are also in line with vertical cooperation. IT capabilities and information exchange can simplify processes, facilitate the coordination of activities among partners in order to reduce risks and support the planning of logistics activities among partners. This is something that is relevant for both horizontal and vertical cooperation.

There is a slight difference in criteria between horizontal and vertical cooperation for the category organization. In this category, the success of vertical cooperation depends on 
IJLM

30,2

criteria like commitment, trust, effective communication and conflict resolution. These are key drivers to reduce costs, improve customer satisfaction and processes (Yang, 2009). Our research emphasizes the importance of cultural fit in horizontal cooperation, which is especially relevant to promote partnership performance and improve business continuity (Svensson, 2004).

\subsection{Toward a starting point for partner evaluation in horizontal LSP networks}

The results of our ANP framework show that the financial (FIN) category is the most important category for strategic partner evaluation in horizontal cooperation among LSPs. The interviews showed that within the financial category, cost (CST) and financial stability (FST) were important criteria. Financial stability (FST) influences the cooperation between LSPs because it allows for joint investment, which results in more efficient use of resources and innovation (Rezaei et al., 2016). This finding is also in line with prior studies on vertical logistics cooperation, which suggest that cooperation is an effective strategy to reduce operational costs which in turn results in positive business outcomes (Cousins, 2005).

The interviews furthermore revealed that the operational performance (PRFM) category is considered second in rank of importance. Since cooperating partners support each other to perform a wider range of flexible services, they reach more customers through a wider geographic reach, optimize utilization of facilities in order to control costs and increase productivity and create innovative solutions for their clients via interfirm specialization (Bernal et al., 2002; Cruijssen, Cools, and Dullaert, 2007; Raue and Wallenburg, 2013). Within the operational performance category, interviewees discussed that service (SER) and quality (QLT) are the key evaluation criteria for horizontal cooperation among LSPs, because customer satisfaction is dependent on the service and quality offered by each partner LSP. This is in line with findings from the literature on vertical logistics cooperation (Kannan and Tan, 2002; Ho et al., 2010; Golmohammadi and Mellat-Parast, 2012).

Third is the category Strategy (STR), in which information exchange (INF) was indicated as the most relevant aspect to evaluate LSP partners on. Prior research (Thakkar et al., 2005; Vanovermeire et al., 2014) indicates that in collaborative engagements information exchange (INF) increases mutual trust and that it is necessary to exchange information not only for daily operations but also to ensure continuous improvement. Information exchange is key to synchronizing flows of goods with information flows in an LSP network as this improves transport efficiency and reduces coordination effort. The importance of information exchange in a collaborative partnership is also reported in vertical logistics cooperation (Sridharan and Simatupang, 2009).

In the organizational (ORG) category, trust (TR) is most important according to the interviews. Trust (TR) enables the communication (CMN) between partners and affects the cultural fit (CF) of partner within an LSP network. Effective communication is important for enabling data transparency between partners, which in turn strengthens the relationship and trust between partners (Yang et al., 2015). Research on vertical partnership also indicates that the right partner is one with a similar organization, culture fit and philosophy (Audy et al., 2012). Because they reflect the manner in which a service is organized or provided to a customer, Trust (TR) and cultural fit (CF) are fundamental to strengthen the relationship and cooperation of a network as explained by the interviewed managers.

\subsection{Conclusions, limitations and future research}

In this paper, we aimed to establish criteria for evaluating strategic partners in a network of LSPs, to show how ANP can be used to identify the weights of these criteria on a casespecific basis and to investigate whether the ANP model can be used as a starting point to evaluate strategic partners for other LSP networks. We consulted the literature on vertical cooperation between LSPs and shippers as well as three LSP managers to develop a list of 
criteria useful for evaluating LSP partners active in horizontal cooperation. We applied these criteria to LSP1 and showed that in that case the most important category was financial criteria (FIN), then performance criteria (PRFM), strategic criteria (STR) and last organizational criteria (ORG). We then applied our ANP model to a second case study (LSP2) to show that the model can be applied to another LSP with similar characteristics. We compared the results of a ranking of five partners by the LSP management team and concluded that this led to relatively similar overall results as when applying the ANP framework developed for LSP1. We then discussed the ANP model in 12 interviews with top-level managers of LSP2 and concluded that the order of importance of the overall categories are as identified in the ANP model, though the priorities of individual criteria may change dependent on the specific characteristics of an LSP and their partners.

This study's results indicated that the differences between vertical and horizontal cooperation in the relative importance (ranking) of LSP partner evaluation criteria are small. These similarities may be useful for other collaborative issues: contracts between partners may, for example, contain similar components in situations of horizontal and vertical collaboration, or performance measurement frameworks may be developed along the same lines. However, managing horizontal cooperation among LSPs may be more difficult than managing vertical cooperation. The sharing of profits and risks of joint operations is a source of conflict inherent in horizontal cooperation among LSPs whereas vertical cooperation is governed by a supplier-customer relation. One may argue that in such a supplier-customer relationship, the customer is a leader and the supplier a follower, whereas this is less apparent in horizontal collaboration partnerships. This may have implications for price setting strategies in horizontal vs vertical partnerships.

It is a well-known fact that trust between partners can make cooperative efforts more effective (Zaefarian et al., 2013). Consequently, adequate governance mechanisms have to be established similarly to vertical cooperation to gain benefits from horizontal collaboration (Wallenburg and Raue, 2011; Schmoltzi and Wallenburg, 2011). The potential of horizontal collaboration for increasing load factors in transport and thereby reducing the environmental impact of transport and logistics has encouraged the European Commission to fund a variety of research projects on these topics. The NEXTRUST project, in particular, aims to increase efficiency and sustainability in logistics by developing interconnected trusted collaborative networks along the entire supply chain and by providing clear guidelines to practitioners on how to set up competition law compliant and more sustainable collaboration networks (see http://nex trust-project.eu/). However, this is a careful balancing act since collaborative partnerships may be considered to be non-competitive and in violation of antitrust laws if the allied firms earn excessive profits at the expense of their competitors (Hoyt and Huq, 2000). Horizontal partnerships thus need to scrutinized frequently on that aspect. Such frequent evaluations may not only prevent antitrust issues from occurring (e.g. the impression of price-fixing), but will also foster an environment of trust between the partners. Research shows that trust is built amongst others by frequent joint activity, but also by providing transparency (Akkermans et al., 2004).

For practitioners, the results of this study might serve as a starting point for a tool to evaluate LSP partners active in horizontal cooperation. ANP may be a useful tool compared to other multi-criteria decision-making tools because of the relative simplicity of using the tool while the results are robust. A structured analysis provided by an ANP model can help reduce the risk of poor decisions regarding partnership improvement or continuation.

Like any study also, our study comes with limitations. First, the approach we have followed does not allow for identifying which individual criteria are the generally speaking most important criteria for evaluating partners in horizontal LSP networks. To answer such a research question would require a different research approach, e.g. involving a large-scale 
IJLM

30,2

survey and the development of hypotheses, similar to what Yang (2009) has done for investigating evaluation criteria in vertical cooperation.

Second, we have verified the general applicability of the order of importance in the categories of evaluation criteria with 12 interviewees. A detailed comparison of evaluation criteria across industries to provide a rationale behind differences between types of industries requires additional in-depth empirical (case) studies in a variety of LSP industries. More specifically, it would be interesting to study LSPs that are entirely different from each other, and, for example, to contrast relatively stable commercial supply chains from, for example, the chemicals industry with supply chains characterized by very high levels of demand volatility and high uncertainty in infrastructure availability and in demand, as experienced in humanitarian relief.

Third, although our case studies indicated that the differences in the relative importance (ranking) of the criteria for vertical and horizontal cooperation are small, it is impossible to draw strong conclusions on whether a distinction between both types of collaboration remains meaningful for partner evaluation. More research is needed to provide strong evidence for the question whether success factors for vertical logistics cooperation are similar to those for horizontal partnerships among LSPs. If differences remain small, it will be interesting to investigate this, e.g., using case studies within LSPs that are active both in an LSP network and in vertical cooperation.

Our interviews indicate that the logistics companies will put more emphasis on delivering services that are not only efficient and effective but also sustainable - both in response to governmental regulations and in order to raise customer awareness regarding environmental protection (Mirhedayatian et al., 2014). Future research should, therefore, focus on the integration and quantification of environmental aspects in partner evaluation criteria in order to achieve a sustainable logistics network.

\section{References}

Akkermans, H., Bogerd, P. and Van Doremalen, J. (2004), “Travail, transparency and trust: a case study of computer-supported collaborative supply chain planning in high-tech electronics", European Journal of Operational Research, Vol. 153 No. 2, pp. 445-456.

Andersson, D. and Norrman, A. (2002), "Procurement of logistics services - a minutes work or a multiyear project?", European Journal of Purchasing and Supply Management, Vol. 8 No. 1, pp. 3-14.

Audy, J.F., Lehoux, N., D’Amours, S. and Rönnqvist, M. (2012), "A framework for an efficient implementation of logistics collaborations", International Transactions in Operational Research, Vol. 19 No. 5, pp. 633-657.

Bayazit, O. (2006), "Use of analytic network process in vendor selection decisions", Benchmarking: An International Journal, Vol. 13 No. 6, pp. 566-579.

Bernal, S.M.H., Burr, C. and Johnsen, R.E. (2002), "Competitor networks: international competitiveness through collaboration: the case of small freight forwarders in the high-tech forwarder network", International Journal of Entrepreneurial Behavior and Research, Vol. 8 No. 5, pp. 239-253.

Bhutta, K.S. and Huq, F. (2002), "Supplier selection problem: a comparison of the total cost of ownership and analytic hierarchy process approaches", Supply Chain Management: An International Journal, Vol. 7 No. 3, pp. 126-135.

Bruno, G., Esposito, E., Genovese, A. and Passaro, R. (2012), "AHP-based approaches for supplier evaluation: problems and perspectives", Journal of Purchasing and Supply Management, Vol. 18 No. 3, pp. 159-172.

Büyüközkan, G. and Görener, A. (2015), "Evaluation of product development partners using an integrated AHP-VIKOR model”, Kybernetes, Vol. 44 No. 2, pp. 220-237.

Büyüközkan, G., Feyzioğlu, O. and Nebol, E. (2008), "Selection of the strategic alliance partner in logistics value chain”, International Journal of Production Economics, Vol. 113 No. 1, pp. 148-158. 
Cao, M., Vonderembse, M.A., Zhang, Q. and Ragu-Nathan, T.S. (2010), "Supply chain collaboration: conceptualization and instrument development", International Journal of Production Research, Vol. 48 No. 22, pp. 6613-6635.

Carbone, V. and Stone, M.A. (2005), "Growth and relational strategies used by the European logistics service providers: rationale and outcomes", Transportation Research Part E: Logistics and Transportation Review, Vol. 41 No. 6, pp. 495-510.

Çelebi, D., Bayraktar, D. and Bingöl, L. (2010), "Analytical network process for logistics management: a case study in a small electronic appliances manufacturer", Computers \& Industrial Engineering, Vol. 58 No. 3, pp. 432-441.

Chan, F.T.S., Chan, H.K., Ip, R.W.L. and Lau, H.C.W. (2007), "A decision support system for supplier selection in the airline industry", Proceedings of the Institution of Mechanical Engineers, Part B: Journal of Engineering Manufacture, Vol. 221 No. 4, pp. 741-758.

Chen, K.-Y. and Wu, W.-T. (2011), "Applying analytic network process in logistics service provider selection - a case study of the industry investing in South East Asia", International Journal of Electronic Business Management, Vol. 9 No. 1, pp. 24-36.

Chen, S.P. and Wu, W.Y. (2010), "A systematic procedure to evaluate an automobile manufacturer-distributor partnership”, European Journal of Operational Research, Vol. 205 No. 3, pp. 687-698.

Cousins, P.D. (2005), "The alignment of appropriate firm and supply strategies for competitive advantage", International Journal of Operations and Production Management, Vol. 25 No. 5, pp. 403-428.

Cruijssen, F., Cools, M. and Dullaert, W. (2007), "Horizontal cooperation in logistics: opportunities and impediments", Transportation Research Part E: Logistics and Transportation Review, Vol. 43 No. 2, pp. 129-142.

Cruijssen, F., Dullaert, W. and Fleuren, H. (2007), "Horizontal cooperation in transport and logistics: a literature review", Transportation Journal, Vol. 46 No. 3, pp. 22-39.

Cruijssen, F., Dullaert, W. and Joro, T. (2010), "Freight transportation efficiency through horizontal cooperation in Flanders", International Journal of Logistics: Research \& Applications, Vol. 13 No. 3, pp. 161-178.

Dean, B.V. and Nishry, M.J. (1965), "Scoring and profitability models for evaluating and selecting engineering projects", Operations Research, Vol. 13 No. 4, pp. 517-687.

Denyer, D. and Tranfield, D. (2009), “Chapter 39: producing a systematic review”, in Buchanan, D. and Bryman, A. (Eds), The Sage Handbook of Organizational Research Methods, Sage Publications Ltd, London, pp. 671-689.

Dickson, G.W. (1966), “An analysis of vendor selection systems and decisions”, Journal of Purchasing, Vol. 2 No. 1, pp. 5-17.

Dyer, J.H. (1997), "Effective interfirm collaboration: how firms minimize transaction costs and maximize transaction value”, Strategic Management Journal, Vol. 18 No. 7, pp. 535-556.

Eisenhardt, K.M. and Graebner, M.E. (2007), "Theory building from cases: opportunities and challenges", The Academy of Management Journal, Vol. 50 No. 1, pp. 25-32.

Forkmann, S., Wang, D., Henneberg, S.C., Naudé, P. and Sutcliffe, A. (2012), "Strategic decision making in business relationships: a dyadic agent-based simulation approach", Industrial Marketing Management, Vol. 41 No. 5, pp. 816-830.

Gencer, C. and Gürpinar, D. (2007), "Analytic network process in supplier selection: a case study in an electronic firm”, Applied Mathematical Modelling, Vol. 31 No. 11, pp. 2475-2486.

Geringer, J.M. (1991), "Strategic determinants of partner selection criteria in international joint ventures", Journal of International Business Studies, Vol. 22 No. 1, pp. 41-62.

Golmohammadi, D. and Mellat-Parast, M. (2012), "Developing a grey-based decision-making model for supplier selection", International Journal of Production Economics, Vol. 137 No. 2, pp. 191-200. 
Ha, B.C., Park, Y.K. and Cho, S. (2011), "Suppliers' affective trust and trust in competency in buyers: its effect on collaboration and logistics efficiency", International Journal of Operations and Production Management, Vol. 31 No. 1, pp. 56-77.

Ho, W., Xu, X. and Dey, P.K. (2010), "Multi-criteria decision-making approaches for supplier evaluation and selection: a literature review", European Journal of Operational Research, Vol. 202 No. 1, pp. 16-24.

Hoyt, J. and Huq, F. (2000), "From arms-length to collaborative relationships in the supply chain: an evolutionary process", International Journal of Physical Distribution \& Logistics Management, Vol. 30 No. 9, pp. 750-764.

Huang, S.H. and Keskar, H. (2007), "Comprehensive and configurable metrics for supplier selection", International Journal of Production Economics, Vol. 105 No. 2, pp. 510-523.

Işıklar, G. and Büyüközkan, G. (2007), "Using a multi-criteria decision making approach to evaluate mobile phone alternatives", Computer Standards \& Interfaces, Vol. 29 No. 2, pp. 265-274.

Jharkharia, S. and Shankar, R. (2007), "Selection of logistics service provider: an analytic network process (ANP) approach”, Omega, Vol. 35 No. 3, pp. 274-289.

Kannan, V.R. and Tan, K.C. (2002), "Supplier selection and assessment: their impact on business performance", Journal of Supply Chain Management, Vol. 38 No. 3, pp. 11-21.

Lai, J.H., Chang, S.C. and Chen, S.S. (2010), “Is experience valuable in international strategic alliances?”, Journal of International Management, Vol. 16 No. 3, pp. 247-261.

Lai, K.H. (2009), "Linking exchange governance with supplier cooperation and commitment: a case of container terminal operations", Journal of Business Logistics, Vol. 30 No. 1, pp. 243-263.

Lambert, D.M. (2008), Supply Chain Management: Processes, Partnerships, Performance, 2nd ed., Supply Chain Management Institute, Sarasota.

Lee, Y. and Cavusgil, S.T. (2006), "Enhancing alliance performance: the effects of contractual-based versus relational-based governance”, Journal of Business Research, Vol. 59 No. 8, pp. 896-905.

Liou, J.J.H. (2012), "Developing an integrated model for the selection of strategic alliance partners in the airline industry”, Knowledge-Based Systems, Vol. 28 No. 1, pp. 59-67.

Liou, J.J.H., Tzeng, G.-H., Tsai, C.-Y. and Hsu, C.C. (2011), "A hybrid ANP model in fuzzy environments for strategic alliance partner selection in the airline industry", Applied Soft Computing, Vol. 11 No. 4, pp. 3515-3524.

Luo, X., Wu, C., Rosenberg, D. and Barnes, D. (2009), "Supplier selection in agile supply chains: an information-processing model and an illustration", Journal of Purchasing and Supply Management, Vol. 15 No. 4, pp. 249-262.

Martin, N., Verdonck, L., Caris, A. and Depaire, B. (2018), "Horizontal collaboration in logistics: decision framework and typology", Operations Management Research, Vol. 11 Nos 1/2, pp. 32-50.

Meade, L.M. and Presley, A. (2002), "R\&D project selection using the analytic network process", IEEE Transactions on Engineering Management, Vol. 49 No. 1, pp. 59-66.

Midoro, R. and Pitto, A. (2000), "A critical evaluation of strategic alliances in liner shipping", Maritime Policy and Management, Vol. 27 No. 1, pp. 31-40.

Miller, R.R. (1998), Selling to Newly Emerging Markets, Greenwood Publishing Group, CT.

Mirhedayatian, S.M., Azadi, M. and Farzipoor Saen, R. (2014), “A novel network data envelopment analysis model for evaluating green supply chain management”, International Journal of Production Economics, Vol. 147, Part B, pp. 544-554.

Panayides, P.M. and Wiedmer, R. (2011), "Strategic alliances in container liner shipping”, Research in Transportation Economics, Vol. 32 No. 1, pp. 25-38.

Pérez-Bernabeu, E., Juan, A.A., Faulin, J. and Barrios, B.B. (2015), "Horizontal cooperation in road transportation: a case illustrating savings in distances and greenhouse gas emissions", International Transactions in Operational Research, Vol. 22 No. 3, pp. 585-606. 
Pomponi, F., Fratocchi, L. and Rossi Tafuri, S. (2015), "Trust development and horizontal collaboration in logistics: a theory based evolutionary framework", Supply Chain Management: An International Journal, Vol. 20 No. 1, pp. 83-97.

Ramanathan, U. (2013), "Aligning supply chain collaboration using analytic hierarchy process", Omega, Vol. 41 No. 2, pp. 431-440.

\section{Strategic \\ partner \\ evaluation \\ criteria}

Raue, J.S. and Wallenburg, C.M. (2013), "Alike or not? Partner similarity and its outcome in horizontal cooperations between logistics service providers", Logistics Research, Vol. 6 No. 4, pp. 217-230.

Rese, M. (2006), "Successful and sustainable business partnerships: how to select the right partners", Industrial Marketing Management, Vol. 35 No. 1, pp. 72-82.

Rezaei, J., Nispeling, T., Sarkis, J. and Tavasszy, L. (2016), “A supplier selection life cycle approach integrating traditional and environmental criteria using the best worst method", Journal of Cleaner Production, Vol. 135 No. 1, pp. 577-588.

Saaty, T.L. and Vargas, L.G. (2012), Models, Methods, Concepts \& Applications of the Analytic Hierarchy Process, Springer Science \& Business Media, New York, NY.

Saen, R.F. (2007), "A new mathematical approach for suppliers selection: accounting for non-homogeneity is important", Applied Mathematics and Computation, Vol. 185 No. 1, pp. 84-95.

Sarkis, J. (1998), "Evaluating environmentally conscious business practices", European Journal of Operational Research, Vol. 107 No. 1, pp. 159-174.

Sarkis, J. and Talluri, S. (2006), "A model for strategic supplier selection”, Journal of Supply Chain Management, Vol. 38 No. 4, pp. 18-28.

Schmoltzi, C. and Wallenburg, C.M. (2011), "Horizontal cooperations between logistics service providers: motives, structure, performance", International Journal of Physical Distribution and Logistics Management, Vol. 41 No. 6, pp. 552-576.

Sevkli, M., Lenny Koh, S.C., Zaim, S., Demirbag, M. and Tatoglu, E. (2007), "An application of data envelopment analytic hierarchy process for supplier selection: a case study of BEKO in Turkey", International Journal of Production Research, Vol. 45 No. 9, pp. 1973-2003.

Sharma, M.J., Moon, I. and Bae, H. (2008), "Analytic hierarchy process to assess and optimize distribution network", Applied Mathematics and Computation, Vol. 202 No. 1, pp. 256-265.

Shashi Kumar, N. (1999), "The US OSRA of 1998: an analysis of its economic impact on carriers, shippers and third parties", Proceedings of the IAME Halifax Conference: Centre for International Business Studies, Dalhousie University, Halifax, p. 7e29.

Simpson, P.M., Siguaw, J.A. and White, S.C. (2002), "Measuring the performance of suppliers: an analysis of evaluation processes", Journal of Supply Chain Management, Vol. 38 No. 4, pp. 29-41.

Solesvik, M.Z. and Westhead, P. (2010), "Partner selection for strategic alliances: case study insights from the maritime industry", Industrial Management \& Data Systems, Vol. 110 No. 6, pp. 841-860.

Sridharan, R. and Simatupang, T. (2009), "Managerial views of supply chain collaboration", Gadjah Mada International Journal of Business, Vol. 11 No. 2, pp. 253-273.

Svensson, G. (2004), "Supplier segmentation in the automotive industry: a dyadic approach of a managerial model", International Journal of Physical Distribution \& Logistics Management, Vol. 34 Nos 1/2, pp. 12-38.

Talluri, S. and Baker, R.C. (2002), "A multi-phase mathematical programming approach for effective supply chain design”, European Journal of Operational Research, Vol. 141 No. 3, pp. 544-558.

Talluri, S., Narasimhan, R. and Nair, A. (2006), "Vendor performance with supply risk: a chance-constrained DEA approach", International Journal of Production Economics, Vol. 100 No. 2, pp. 212-222.

Teo, T.S., Lin, S. and Lai, K.H. (2009), “Adopters and non-adopters of e-procurement in Singapore: an empirical study", Omega, Vol. 37 No. 5, pp. 972-987. 
Thakkar, J., Deshmukh, S.G., Gupta, A.D. and Shankar, R. (2005), "Selection of third-party logistics (3PL): a hybrid approach using interpretive structural modeling (ISM) and analytic network process (ANP)", Supply Chain Forum AN International Journal, Vol. 6 No. 1, pp. $32-46$.

Tseng, M.-L., Lin, Y.-H. and Chiu, A.S.F. (2009), "Fuzzy AHP-based study of cleaner production implementation in Taiwan PWB manufacturer", Journal of Cleaner Production, Vol. 17 No. 14, pp. 1249-1256.

Vanovermeire, C., Sörensen, K., Van Breedam, A., Vannieuwenhuyse, B. and Verstrepen, S. (2014), "Horizontal logistics collaboration: decreasing costs through flexibility and an adequate cost allocation strategy", International Journal of Logistics Research and Applications, Vol. 17 No. 4, pp. 339-355.

Verdonck, L. (2017), "Collaborative logistics from the perspective of freight transport companies", dissertation, Hasselt University, Hasselt.

Verstrepen, S., Cools, M.F., Cruijssen, F. and Dullaert, W.W.E.H. (2009), "A dynamic framework for managing horizontal cooperation in logistics", International Journal Logistics Systems and Management, Vol. 5 Nos 3/4, pp. 228-248.

Wallenburg, C.M. and Raue, J.S. (2011), "Conflict and its governance in horizontal cooperations of logistics service providers", International Journal of Physical Distribution \& Logistics Management, Vol. 41 No. 4, pp. 385-400.

Wang, L. and Kess, P. (2006), "Partnering motives and partner selection: case studies of Finnish distributor relationships in China", International Journal of Physical Distribution \& Logistics Management, Vol. 36 No. 6, pp. 466-478.

Weber, C.A., Current, J.R. and Benton, W.C. (1991), "Vendor selection criteria and methods", European Journal of Operational Research, Vol. 50 No. 1, pp. 2-18.

Wu, C. and Barnes, D. (2010), "Formulating partner selection criteria for agile supply chains: a Dempster-Shafer belief acceptability optimization approach", International Journal of Production Economics, Vol. 125 No. 2, pp. 284-293.

Wu, C. and Barnes, D. (2011), "A literature review of decision-making models and approaches for partner selection in agile supply chains", Journal of Purchasing and Supply Management, Vol. 17 No. 4, pp. 256-274.

Yang, J. (2009), "The determinants of supply chain alliance performance: an empirical study", International Journal of Production Research, Vol. 47 No. 4, pp. 1055-1069.

Yang, J., Lai, K.H., Wang, J., Rauniar, R. and Xie, H. (2015), "Strategic alliance formation and the effects on the performance of manufacturing enterprises from supply chain perspective", International Journal of Production Research, Vol. 53 No. 13, pp. 3856-3870.

Zacharia, Z.G., Nix, N.W. and Lusch, R.F. (2009), "An analysis of supply chain collaborations and their effect on performance outcomes", Journal of Business Logistics, Vol. 30 No. 2, pp. 101-123.

Zaefarian, G., Henneberg, S.C. and Naudé, P. (2013), "Assessing the strategic fit between business strategies and business relationships in knowledge-intensive business services", Industrial Marketing Management, Vol. 42 No. 2, pp. 260-272.

Zahedi, F. (1986), "The analytic hierarchy process - a survey of the method and its applications", Interfaces, Vol. 16 No. 4, pp. 96-108.

Zeydan, M., Çolpan, C. and Çobanoğlu, C. (2011), "A combined methodology for supplier selection and performance evaluation”, Expert Systems with Applications, Vol. 38 No. 3, pp. 2741-2751. 


\begin{tabular}{|c|c|c|c|c|c|c|c|c|}
\hline Strategic criteria & INF & INV & LTE & IT & NTW & & & \\
\hline Information exchange (INF) & 1 & 2 & 3 & 4 & 6 & 0.790 & 0.422 & 461 \\
\hline Inventory turnover (INV) & $1 / 2$ & 1 & 2 & 3 & 4 & 0.482 & 0.257 & \\
\hline Long-term engagement (LTE) & $1 / 3$ & $1 / 2$ & 1 & 2 & 4 & 0.310 & 0.166 & \\
\hline IT capability (IT) & $1 / 4$ & $1 / 3$ & $1 / 2$ & 1 & 3 & 0.195 & 0.104 & \\
\hline Network (NTW) & $1 / 6$ & $1 / 4$ & $1 / 4$ & $1 / 3$ & 1 & 0.096 & 0.051 & \\
\hline Consistency ratio & 0.026 & & & & & & & \\
\hline Organizational criteria & TR & $\mathrm{KH}$ & $\mathrm{CF}$ & $\mathrm{CMN}$ & FB & & & \\
\hline Trust (TR) & 1 & 3 & 4 & 4 & 6 & 0.851 & 0.475 & \\
\hline Know-how (KH) & $1 / 3$ & 1 & 2 & 3 & 4 & 0.411 & 0.229 & \\
\hline Cultural fit (CF) & $1 / 4$ & $1 / 2$ & 1 & 2 & 3 & 0.255 & 0.142 & \\
\hline Communication (CMN) & $1 / 4$ & $1 / 3$ & $1 / 2$ & 1 & 3 & 0.182 & 0.102 & \\
\hline Family business (FB) & $1 / 6$ & $1 / 4$ & $1 / 3$ & $1 / 3$ & 1 & 0.094 & 0.052 & \\
\hline Consistency ratio & 0.038 & & & & & & & \\
\hline Financial criteria & CST & FST & REV & SAL & & & & \\
\hline Costs (CST) & 1 & 2 & 4 & 6 & & 0.794 & 0.483 & \\
\hline Financial stability (FST) & $1 / 2$ & 1 & 5 & 5 & & 0.573 & 0.349 & \\
\hline Revenue sharing (REV) & $1 / 4$ & $1 / 5$ & 1 & 2 & & 0.170 & 0.103 & \\
\hline Sales (SAL) & $1 / 6$ & $1 / 5$ & $1 / 2$ & 1 & & 0.107 & 0.065 & \\
\hline Consistency ratio & 0.040 & & & & & & & \\
\hline Operational performance criteria & SER & QLT & DLV & GRW & & & & \\
\hline Service (SER) & 1 & 2 & 3 & 6 & & 0.811 & 0.476 & Table AI. \\
\hline Quality (QLT) & $1 / 2$ & 1 & 2 & 5 & & 0.492 & 0.289 & Pairwise comparison \\
\hline Delivery (DLV) & $1 / 3$ & $1 / 2$ & 1 & 4 & & 0.299 & 0.176 & matrices of individual \\
\hline Growth (GRW) & $1 / 6$ & $1 / 5$ & $1 / 4$ & 1 & & 0.101 & 0.059 & criteria by categories \\
\hline Consistency ratio & 0.025 & & & & & & & (from ANP Step 3) \\
\hline
\end{tabular}




\begin{tabular}{l}
\hline \\
\hline INF as dependent \\
Inventory turnover (INV) \\
Long-term engagement (LTE) \\
IT capability (IT) \\
Network (NTW) \\
Consistency ratio \\
INV as dependent \\
Information exchange (INF) \\
Long-term engagement (LTE) \\
IT capability (IT) \\
Network (NTW) \\
Consistency ratio \\
LTE as dependent \\
Information exchange (INF) \\
Inventory turnover (INV) \\
IT capability (IT) \\
Network (NTW) \\
Consistency ratio \\
IT as dependent
\end{tabular}

e-vector

Normalized e-vector

\section{2}

IT as dependent

Information exchange (INF)

Inventory turnover (INV)

Long-term engagement (LTE)

Network (NTW)

Consistency ratio

NTW as dependent

Information exchange (INF)

Inventory turnover (INV)

Long-term engagement (LTE)

IT capability (IT)

Consistency ratio

TR as dependent

Know-how (KH)

Cultural fit (CF)

Communication (CMN)

Family business (FB)

Consistency ratio

$\mathrm{KH}$ as dependent

Trust (TR)

Cultural fit (CF)

Communication (CMN)

Family Business (FB)

Consistency ratio

$\mathrm{CF}$ as dependent

Trust (TR)

Know-how (KH)

Table AII.

Communication (CMN)

Pair wise comparison

Family Business (FB)

matrices for

Consistency ratio

e-vector

$\begin{array}{lrrrrr}\text { INV } & \text { LTE } & \text { IT } & \text { NTW } & & \\ 1 & 1 / 6 & 1 / 4 & 1 / 2 & 0.083 & 0.047 \\ 6 & 1 & 4 & 3 & 0.711 & 0.402 \\ 4 & 1 / 4 & 1 & 2 & 0.410 & 0.232 \\ 2 & 1 / 3 & 1 / 2 & 1 & 0.566 & 0.320\end{array}$

0.271

INF LTE IT NTW

$\begin{array}{lrrr}1 & 5 & 4 & 1 / 2\end{array}$

0.699

0.126

0.485

0.384

$\begin{array}{rrrr}1 / 5 & 1 & 1 / 2 & 1 / 4 \\ 1 / 4 & 2 & 1 & 3\end{array}$

2

0.340

INF INV

$1 / 3$

0.511

0.069

0.281

$\begin{array}{ll}1 & 1 / 5 \\ 5 & \end{array}$

$4 \quad 1 / 3$

$1 / 2$

0.077

INF INV LTE NTW

IT NTW

NTW
2

0.177

0.867

0.109

0.443

0.533

3

0.443

0.272

$1 / 3$

1

0.087

$\begin{array}{rrr}1 & 1 / 3 & 1 / 4 \\ 3 & 1 & 1 / 2\end{array}$

3

4

$1 / 3$

0.071

INF INV

$1 \quad 1 / 2$

$\begin{array}{rr}2 & 1 \\ 1 / 4 & 1 / 5\end{array}$

$1 / 5 \quad 1 / 6$

0.094

KH $\quad \mathrm{CF} \quad \mathrm{CMN} \quad \mathrm{FB}$

$1 \quad 1 / 5 \quad 1 / 6$

2

$\begin{array}{llll}5 & 1 & 1 / 2 & 3\end{array}$

6

$1 / 2$

0.150

2
$1 / 3$

1
$1 / 2$

$\begin{array}{ll}\text { TR } & \text { CF } \\ 1 & 1 / 3\end{array}$

1
3

3
$1 / 2$

3

0.277

TR
1
$1 / 3$
4
6

0.069

0.235

0.140

0.510

0.819

0.303

0.487

0.119

0.071

interdependencies (from ANP step 4)

$\begin{array}{rrrr}\text { CMN } & \text { FB } & & \\ 2 & 1 / 3 & 0.291 & 0.151 \\ 1 / 3 & 1 / 2 & 0.661 & 0.343 \\ 1 & 2 & 0.438 & 0.228 \\ 1 / 2 & 1 & 0.535 & 0.278\end{array}$

CMN FB

$1 / 4 \quad 1 / 6$

0.181

0.111

$0.103 \quad 0.063$

$0.519 \quad 0.318$

$0.829 \quad 0.508$

0.325

0.501

0.067

0.107

0.109

0.779

0.451

0.114

\section{1}

0.228

0.278

$\begin{array}{rr}1 / 5 & 1 / 5 \\ 1 & 1 / 2\end{array}$

0.508

(continued) 


\begin{tabular}{|c|c|c|c|c|c|c|c|}
\hline & & & & & e-vector & Normalized e-vector & $\begin{array}{r}\text { Strategic } \\
\text { partner }\end{array}$ \\
\hline CMN as dependent & $\mathrm{TR}$ & $\mathrm{KH}$ & $\mathrm{CF}$ & $\mathrm{FB}$ & & & evaluation \\
\hline Trust (TR) & 1 & 5 & 2 & 3 & 0.796 & 0.459 & criteria \\
\hline Know-how (KH) & $1 / 5$ & 1 & $1 / 4$ & $1 / 6$ & 0.106 & 0.061 & \\
\hline Cultural fit (CF) & $1 / 2$ & 4 & 1 & 2 & 0.478 & 0.276 & \\
\hline $\begin{array}{l}\text { Family business (FB) } \\
\text { Consistency ratio }\end{array}$ & $\begin{array}{l}1 / 3 \\
0.077\end{array}$ & 6 & $1 / 2$ & 1 & 0.355 & 0.205 & 463 \\
\hline FB as dependent & TR & $\mathrm{KH}$ & $\mathrm{CF}$ & $\mathrm{CMN}$ & & & \\
\hline Trust (TR) & 1 & 4 & $1 / 3$ & $1 / 2$ & 0.3 & 0.176 & \\
\hline Know-how (KH) & $1 / 4$ & 1 & $1 / 6$ & $1 / 5$ & 0.101 & 0.059 & \\
\hline Cultural fit (CF) & 3 & 6 & 1 & 2 & 0.811 & 0.476 & \\
\hline Communication (CMN) & 2 & 5 & $1 / 2$ & 1 & 0.492 & 0.289 & \\
\hline Consistency ratio & 0.026 & & & & & & \\
\hline CST as dependent & FST & REV & SAL & & & & \\
\hline Financial Stability (FST) & 1 & $1 / 6$ & $1 / 4$ & & 0.121 & 0.085 & \\
\hline Revenue sharing (REV) & 6 & 1 & 3 & & 0.915 & 0.644 & \\
\hline Sales (SAL) & 4 & $1 / 3$ & 1 & & 0.384 & 0.270 & \\
\hline Consistency ratio & 0.046 & & & & & & \\
\hline FST as dependent & CST & REV & SAL & & & & \\
\hline Costs (CST) & 1 & $1 / 4$ & $1 / 6$ & & 0.106 & 0.079 & \\
\hline Revenue sharing (REV) & 4 & 1 & $1 / 5$ & & 0.285 & 0.212 & \\
\hline Sales (SAL) & 6 & 5 & 1 & & 0.953 & 0.709 & \\
\hline Consistency ratio & 0.139 & & & & & & \\
\hline REV as dependent & CST & FST & SAL & & & & \\
\hline Costs (CST) & 1 & 4 & $1 / 5$ & & 0.272 & 0.205 & \\
\hline Financial stability (FST) & $1 / 4$ & 1 & $1 / 7$ & & 0.096 & 0.072 & \\
\hline Sales (SAL) & 5 & 7 & 1 & & 0.958 & 0.722 & \\
\hline Consistency ratio & 0.104 & & & & & & \\
\hline SAL as dependent & CST & FST & REV & & & & \\
\hline Costs (CST) & 1 & 6 & $1 / 3$ & & 0.478 & 0.323 & \\
\hline Financial stability (FST) & $1 / 6$ & 1 & $1 / 4$ & & 0.132 & 0.089 & \\
\hline Revenue sharing (REV) & 3 & 4 & 1 & & 0.868 & 0.587 & \\
\hline Consistency ratio & 0.224 & & & & & & \\
\hline SER as dependent & QLT & DLV & GRW & & & & \\
\hline Quality (QLT) & 1 & $1 / 4$ & 5 & & 0.333 & 0.244 & \\
\hline Delivery (DLV) & 4 & 1 & 7 & & 0.938 & 0.687 & \\
\hline Growth (GRW) & $1 / 5$ & $1 / 7$ & 1 & & 0.095 & 0.070 & \\
\hline Consistency ratio & 0.110 & & & & & & \\
\hline QLT as dependent & SER & DLV & GRW & & & & \\
\hline Service (SER) & 1 & $1 / 3$ & 5 & & 0.410 & 0.288 & \\
\hline Delivery (DLV) & 3 & 1 & 6 & & 0.905 & 0.635 & \\
\hline Growth (GRW) & $1 / 5$ & $1 / 6$ & 1 & & 0.111 & 0.078 & \\
\hline Consistency ratio & 0.081 & & & & & & \\
\hline DLV as dependent & SER & QLT & GRW & & & & \\
\hline Service (SER) & 1 & 4 & 8 & & 0.956 & 0.717 & \\
\hline Quality (QLT) & $1 / 4$ & 1 & 3 & & 0.274 & 0.205 & \\
\hline Growth (GRW) & $1 / 8$ & $1 / 3$ & 1 & & 0.104 & 0.078 & \\
\hline Consistency ratio & 0.014 & & & & & & \\
\hline GRW as dependent & SER & QLT & DLV & & & & \\
\hline Service (SER) & 1 & 5 & 4 & & 0.947 & 0.683 & \\
\hline Quality (QLT) & $1 / 5$ & 1 & $1 / 2$ & & 0.162 & 0.117 & \\
\hline Delivery (DLV) & $1 / 4$ & 2 & 1 & & 0.277 & 0.200 & \\
\hline Consistency ratio & 0.022 & & & & & & Table AII. \\
\hline
\end{tabular}


IJLM

30,2

\section{Research study}

\section{“Partner Evaluation Criteria for Horizontal Collaboration among Logistics Service Providers"}

\section{Objectives of the research study:}

- Identification and verification of essential criteria for Partner Evaluation Criteria for Horizontal Collaboration among Logistics Service Providers

- Development of a framework that is capable of supporting decision making in both the monitoring and evaluation of partners within horizontal cooperation among LSPs

- Elaboration of challenges in this field

\section{Working instructions:}

- The time exposure for an Interview in is approx. 35 minutes

- The data collected will be dealt with in strict confidence and used exclusively for scientific research purposes. The data will be analyzed anonymously

(1) Do you use an evaluation framework or how do you evaluate partner?

(2) Could you evaluate five partners of your logistics network using 1 to 5 ranking system.

(1)

(3) Please evaluate the performance of following partner (see table) using the scale from 1 (very poor) to 9 (exceptional) 


\begin{tabular}{|c|c|c|c|c|c|c|}
\hline \multirow[t]{2}{*}{ Category } & \multirow[t]{2}{*}{ Criterion } & \multicolumn{5}{|c|}{ Partner } \\
\hline & & 1 & 2 & 3 & 4 & 5 \\
\hline \multicolumn{7}{|l|}{ Strategic (STR) } \\
\hline Information exchange (INF) & INF & & & & & \\
\hline Inventory turnover (INV) & INV & & & & & \\
\hline Long-term engagement (LTE) & LTE & & & & & \\
\hline IT capability (IT) & IT & & & & & \\
\hline Network (NTW) & NTW & & & & & \\
\hline \multicolumn{7}{|l|}{ Organizational (ORG) } \\
\hline Trust (TR) & TR & & & & & \\
\hline Know-how (KH) & $\mathrm{KH}$ & & & & & \\
\hline Cultural fit (CF) & $\mathrm{CF}$ & & & & & \\
\hline Communication (CMN) & CMN & & & & & \\
\hline Family business (FB) & FB & & & & & \\
\hline \multicolumn{7}{|l|}{ Financial (FIN) } \\
\hline Costs (CST) & CST & & & & & \\
\hline Financial stability (FST) & FST & & & & & \\
\hline Revenue sharing (REV) & REV & & & & & \\
\hline Sales (SAL) & SAL & & & & & \\
\hline \multicolumn{7}{|l|}{ Performance (PRFM) } \\
\hline Service (SER) & SER & & & & & \\
\hline Quality (QLT) & QLT & & & & & \\
\hline Delivery (DLV) & DLV & & & & & \\
\hline Growth (GRW) & GRW & & & & & \\
\hline
\end{tabular}

Strategic

partner

evaluation

criteria

(4) What is your reflection on these questions?

(5) Do you wish results of our research study?

YES $\square \quad$ NO $\square$

Name:

Address:

E-mail address

Thank you for your support! 


\section{Appendix 4}

\section{Questionnaire II}

\section{Questionnaire}

Dear participant,

The information obtained from this questionnaire will contribute to the process of developing a benchmarking tool, that enables decision-makers to structure the decision-making process regarding the evaluation for LSP partner. This questionnaire consists of a list of potentially important evaluation and criteria. The purpose of this questionnaire is to identify important criteria and their relative importance. This questionnaire also supports putting the criteria into practice. All the information obtained from this questionnaire serve as the input for our models and will be handled confidentially.

\begin{tabular}{|l|l|}
\hline \multicolumn{2}{|c|}{ General Information } \\
\hline Name: & \\
\hline Job title: & \\
\hline Department: & \\
\hline Main responsibility: & \\
\hline & \\
Your role in agent selection process & \\
\hline
\end{tabular}

Note: Your name will stay confidential and will NOT appear in any documents

\section{Evaluation Criteria}

\begin{tabular}{|c|c|}
\hline Open question: & $\begin{array}{l}\text { If you are evaluating a partner, which criteria would you add in our ANP model? } \\
\text { Please mention } 5 \text { of them. }\end{array}$ \\
\hline 1. & \\
\hline 2. & \\
\hline 3. & \\
\hline 4. & \\
\hline 5. & \\
\hline Why are followin & important for a partnership among an LSP network. \\
\hline Please provide us & $\mathrm{k}$ on each ranking of following criteria. \\
\hline $\begin{array}{l}\text { Why is a partner } \\
\text { evaluation framev }\end{array}$ & mework important for an LSP network? Please tell us the advantage of such an \\
\hline Do you use an eva & ework or how do you evaluate partner? \\
\hline
\end{tabular}

\section{Corresponding author}

Sander De Leeuw can be contacted at: sander.de.leeuw@vu.nl

For instructions on how to order reprints of this article, please visit our website: www.emeraldgrouppublishing.com/licensing/reprints.htm Or contact us for further details: permissions@emeraldinsight.com 